Animal Health Research Institute, Assiut Regional Laboratry.

\title{
STUDIES ON LISTERIA MONOCYTOGENES IN IMPORTED FROZEN MEAT AND MACKEREL FISH IN ASSUIT GOVERNORATE
}

(With 3 Tables)

By

A.M. MANAA; H.H. ESSA and N.H. MAKAR

(Received at 20/10/2009)

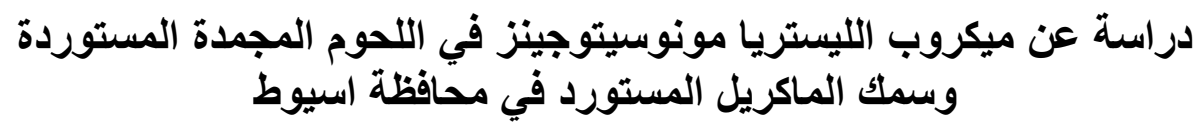

احد مدلوح مناع ، حدي حسين عيسي ، نبيل حبيب مقار

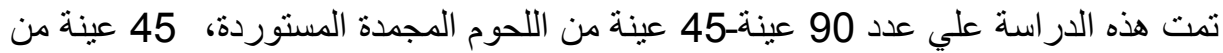

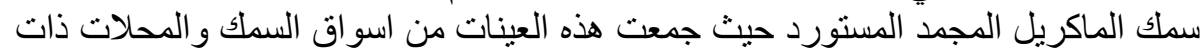

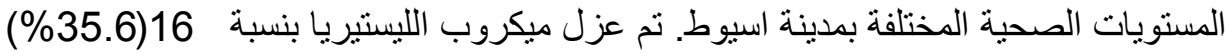

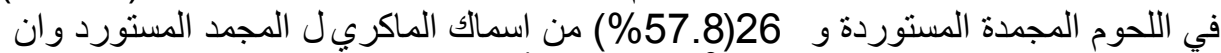

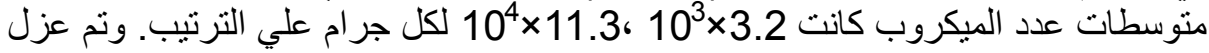

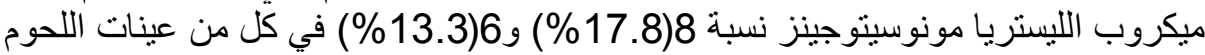

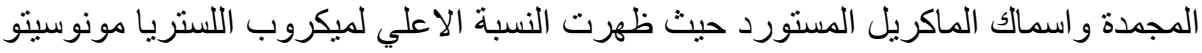

جينز في عينات اللحوم المجمدة المستوردة ولقد تم عمل اختبار حساسية للمضادات الحيوية

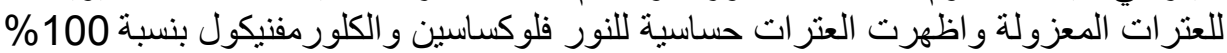

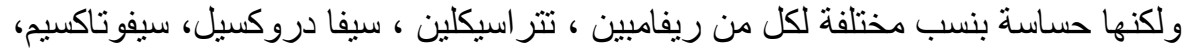

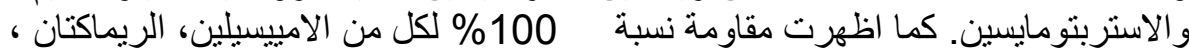

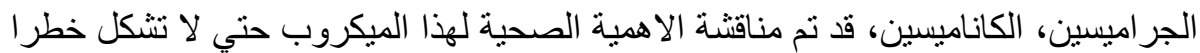
علي صحة المستهلك.

\section{SUMMARY}

This study was carried out on 90 imported frozen samples of meat and mackerel fish (45 each). These samples were obtained from different shops and markets of varied sanitary levels at Assuit city. Listeria species were isolated from $35.6 \%$ of frozen meat and $57.8 \%$ of frozen mackerel fish with an average counts of $3.2 \times 10^{3}$ and $11.3 \times 10^{4} / \mathrm{g}$ respectively. Listeria monocytogenes was differentially identified from other Listeria species and could be isolated at variable percentages 
$17.8 \%$ and $13.3 \%$ in the imported frozen meat and mackerel fish samples. The study revealed that the incidence of Listeria monocytogenes was higher in imported frozen meat as compared to frozen mackerel fish. Antibiogram for the. Listeria monocytogenes revealed that the isolates were susceptible (100\%) to norfloxacin and chloramphenicol and showed different degrees of antimicrobial sensitivity reactions for rifampin, tetracycline, cefadroxil, cefataxime and streptomycin while all isolates (100\%) were resistant to ampicillin, rimactan, garamycin and kanamycin. The hygienic and public health importance of the isolated organisms were discussed.

Key words: Listeria spp., Frozen meat, mackerel fish, antibiogram.

\section{INTRODUCTION}

Listeria species including L.monocytogenes are ubiquitous microorganisms, which can found in the environment and contaminated food. There are six species of Listeria: L.monocytogenes, L.ivanovii, L.seeligeri, greyi, L.innocua and, L.welshimri. Two of these species, are considered to be pathogenic to human especially the young, olderly, and immunocompromised (Jorgenses, and Huss, 1998) while L.ivanovii is pathogenic to animals as reported by Farber, and Peterkin, (1991). Several reports have described the presence of L.monocytogenes in vegetable, dairy and meat products, as well as in fish and sea food (Fletcher, et al., 1994.,. Simon, et al., 1992., Farber, et al., 1989).

L. monocytogenes grows at low oxygen condition and refrigeration temperatures and survives for long periods in the environment, on foods, and in the house hold refrigerator (FAD, 1999; Ryser and Marth, 1991). Food borne disease by Listeria monocytogenes has recently been reported in many countries although contamination by this bacteria is also known to be gradually spreading among the marketed foods of Japan, several isolates of Listera monocytogenes from meats and fish were obtained from different Japan shops (Cossart et al., 2003; Okutani, et al., 2004). In Japan wide contamination by L.monocytogenes has also been found in marketed meats, fish and processed foods (Okutani et al., 2004).

The ingestion of Listeria species especially L. monocytogenes in food can pose a significant health risk, with high reported mortality rate for fetuses and immunocompramized patients. Thus it is important to prevent the contamination of foods like frozen beef, and sea foods with 
Listeria species, emphasizing the need for reliable procedures to test the presence of the pathogens in such food (Gian Franceschi, et al., 2003 and Mena, et al., 2004). Ben Embrek, (1994), Loncarevic, et al. (1998), Ebraheem and Thabet, (2007) reported the incidence of Listeria monocytogenes in frozen beef, poultry, fish and sea foods. Meat and meat products have frequently been contaminated with L.monocytogenes and may serve as vehicle of other pathogenic organisms. In human, the illness may range from mild to severe sickness. The severe forms of human listeriosis are meningoencephalitis followed by septic infections and occasionally isolated organ involvement (Demetrios, et al., 1996 and Lida et al., 1998). Listeria is also of major veterinary importance, and the primary clinical manifestations in cattle are encephalitis and mastitis (Schuchat, et al., 1992). Listeria has been reported to be able to grow over a wide temperature range and are capable of growth under a variety of oxygen conditions, thus, this organism can survive and grow in refrigerated foods, since the organism can grow at refrigerator food there is also concerv that this may contribute to the increased Listeria population (Pinner et al., 1992). Because its ability to survive and proliferation at refrigeration temperature L. monocytogenes may cause disease through frozen foods (Schillinger et al., 1991). Consequently, it was decided to examine these foods in order to establish some indication of the incidence of L. monocytogenes and assess whether the level of contamination might pose any risk to consumers.

\section{MATERIALS and METHODS}

\section{I- Collection of samples:}

Ninety random samples of imported frozen meat and mackerel fish (45 of each) were collected from different fishery markets and shops in Assuit city to be investigated for the presence of Listeria monocytogenes. All samples were collected in sterile polyethylene bags and were transferred to the laboratory in an ice box then were kept at 0 $4^{\circ} \mathrm{c}$ until tested within $24 \mathrm{~h}$.

\section{II- Bacteriological examination: \\ a- Isolation of $L$. monocytogenes from samples:}

According to FAO (1992), twenty five g from each sample were added to $225 \mathrm{ml}$ of Listeria enrichment broth (L.E.B.) then incubated at $30^{\circ} \mathrm{C}$ for $48 \mathrm{~h}$. The enrichment culture was streaked on PALCAM selective agar and incubated at $30^{\circ} \mathrm{C}$ for $24-48 \mathrm{~h}$.

b- Enumeration of $L$. monocytogenes from the examined samples: 
Counting of L. monocytogenes was recorded by direct plating of decimal dilutions of the prepared samples (APHA.1992) onto plates of PALCAM agar. The plates were incubated at $35 \mathrm{C}^{\circ}$ for $24-48 \mathrm{~h}$. and typical colonies presumed to be Listeria monocytogenes were counted c- Identification of $L$. monocytogenes from the examined samples:

Colonies suspected to be L. monocytogenes were identified according to Koneman et al. (1996); Margoles et al. (2000) Quinn et al. (2002); by Gram stain, tumbling motility, V.P. Catalase, Oxidase, haemolysis on horse blood agar and CAMP test. For further confirmation of L. monocytogenes the isolates were incubated into $10 \%$ aqueous stock solution of mannitol, L.Rhamnose and D xylose as described by Collee and Miles (1989)

\section{III- Antibiotic sensitivity tests for listeria isolates:}

All isolates obtained in this study were tested for antimicrobial susceptibility by disc diffusion method as described by Fimegold and Martin.(1982) using 11 antimicrobial agents, using the following discs, Tetracycline (30ug), Rifampin (5ug), Cefadroxil (30ug) Cefotaxime (30ug), Ampicillin (10ug), Rimectan (30ug), Kanamycin (30ug), Garamycin (30ug), Stereptomycin (10ug), Norfloxacin (10ug), and Chloramphenical (30ug).

\section{RESULTS}

Table 1: Incidence of Listeria species and listeria monocytogenes in imported frozen and mackerel fish samples.

\begin{tabular}{|c|c|c|c|c|c|}
\hline \multirow{2}{*}{$\begin{array}{c}\text { Type of } \\
\text { samples }\end{array}$} & \multirow{2}{*}{$\begin{array}{c}\text { No.of } \\
\text { examined } \\
\text { samples }\end{array}$} & \multicolumn{2}{|c|}{$\begin{array}{c}\text { Positive samples of } \\
\text { Listeria species }\end{array}$} & \multicolumn{2}{|c|}{$\begin{array}{c}\text { Positive samples of } \\
\text { L. momocytogenes }\end{array}$} \\
\cline { 3 - 6 } & 45 & 16 & 35.6 & 8 & 17.8 \\
\hline Imported frozen meat & 45 & 26 & 57.8 & 6 & 13.3 \\
\hline $\begin{array}{l}\text { Imported frozen } \\
\text { mackerel fish }\end{array}$ & 90 & 42 & 46.7 & 14 & 15.6 \\
\hline \multicolumn{1}{c|}{ Total } & & No. & $\%$ & No. & $\%$ \\
\hline
\end{tabular}

Table 2: Statistical values of Listeria species in the examined samples. 
Assiut Vet. Med. J. Vol. 56 No. 124 January 2010

\begin{tabular}{|c|c|c|c|}
\hline Type of samples & Minimum & Maximum & Mean \\
\hline $\begin{array}{c}\text { Imported frozen } \\
\text { meat }\end{array}$ & $1 \times 10^{3}$ & $4.9 \times 10^{3}$ & $3.2 \times 10^{3}$ \\
\hline $\begin{array}{c}\text { Imported frozen } \\
\text { mackerel fish }\end{array}$ & $5 \times 10^{4}$ & $18.4 \times 10^{4}$ & $11.3 \times 10^{4}$ \\
\hline
\end{tabular}

Table 3: Antibiogram sensitivity test for Listeria monocytogenes isolates.

\begin{tabular}{|l|c|c|c|c|}
\hline \multirow{2}{*}{ Antibiotic agent } & \multicolumn{2}{|c|}{$\begin{array}{c}\text { Frozen mackerel fish } \\
(6 \text { isolates) }\end{array}$} & \multicolumn{2}{c|}{$\begin{array}{c}\text { Frozen meat } \\
(8 \text { isolates) }\end{array}$} \\
\cline { 2 - 5 } & $\begin{array}{c}\text { Sensitive } \\
\%\end{array}$ & $\begin{array}{c}\text { Resistant } \\
\%\end{array}$ & $\begin{array}{c}\text { Sensitive } \\
\%\end{array}$ & $\begin{array}{c}\text { Resistant } \\
\%\end{array}$ \\
\hline Tetracycline & $3(50 \%)$ & $3(50 \%)$ & $5(62.5 \%)$ & $3(37.5 \%)$ \\
\hline Rifampin & $5(83.3 \%)$ & $1(16.7 \%)$ & $7(87.5 \%)$ & $1(12.5 \%)$ \\
\hline Cefadroxil & $4(66.7 \%)$ & $2(33.3 \%)$ & $6(75 \%)$ & $2(25 \%)$ \\
\hline Cefotaxime & $4(66.7 \%)$ & $2(33.3 \%)$ & $5(62.5 \%)$ & $3(67.5 \%)$ \\
\hline Amipicillin & $0(0.0 \%)$ & $6(100 \%)$ & $0(0.0 \%)$ & $8(100 \%)$ \\
\hline Rimectan & $0(0.0 \%)$ & $6(100 \%)$ & $0(0.0 \%)$ & $8(100 \%)$ \\
\hline Kanamycin & $0(0.0 \%)$ & $6(100 \%)$ & $0(0.0 \%)$ & $8(100 \%)$ \\
\hline Garamycin & $0(0.0 \%)$ & $6(100 \%)$ & $0(0.0 \%)$ & $8(100 \%)$ \\
\hline Streptomycin & $4(66.7)$ & $2(33.3 \%)$ & $6(75 \%)$ & $2(25 \%)$ \\
\hline Norfloxacin & $6(100 \%)$ & $0(0.0 \%)$ & $8(100 \%)$ & $0(0.0 \%)$ \\
\hline Chloramphenicol & $6(100 \%)$ & $0(100 \%)$ & $8(100 \%)$ & $0(0.0 \%)$ \\
\hline
\end{tabular}

\section{DISCUSSION}

The recorded results in Table (1) revealed that $46.7 \%$ of Listeria spp. were isolated from 42 out of 90 samples of imported frozen meat and imported frozen mackerel fish. The percentages of Listeria spp; in each product was $35.6 \%$ and $57.8 \%$ respectively, while $15.6 \%$ of Listeria monocytogenes were isolated from 14 out of 90 samples. The organism was found in $17.8 \%$ of imported frozen meat and $13.3 \%$ of frozen mackerel fish (Table1). The percentages of Listeria spp. in imported frozen meat $(35.6 \%)$ was higher than that recorded by Ebraheem and Thabet (2007), (33\%), while the obtained results were lower than that reported by Elgazzar and Sallam (1997); Hassan et al. (2001) (73.9\%)

On other hand, the incidence of L. monocytogenes in the same product was $17.8 \%$ which was higher than that recorded by Paul et al. (1998), Scange et al. (2000) Ebraheem and Thabet (2007), who recorded 
$16.6 \%, 0.59 ? \%$ and $6.3 \%$ respectively, while the result in this study was lower than that recorded by Nicolos and Vidand (1987) (26.2\%) and Hassan et al. (2001) (75\%) at the same table the incidence of Listeria spp. in frozen mackerel fish was $(57.8 \%)$ which was higher than that obtained by Ebraheem and Thabet (2007) (53\%), Ronda and Thaker (1992) (35)\% but was lower than Weagant et al. (1988) (61\%). Many investigations detected the presence of L. monocytogenes in frozen fish, Ebraheem and Thabet (2007) recorded 13.3\%, Wong et al. (1990) recorded 10.5\%, Ibrahim and Hassan (2006) recorded 9.3\%. Such results nearly agreed with that obtained in this study (13.3\%) while Weagant et al. (1988) recorded 26\%. L. monocytogenes of greatest concern from public health point of view. Dalton et al. (2004) in their studies about food borne diseases outbreaks, found that the most frequently implicated vehicles in 17.3 outbreaks were seafood and L. monocytogenes caused $40 \%$ of deaths.

Table (2) shows that the count of Listeria spp. in the examined imported frozen meat samples ranged from $1 \times 10^{3}$ to $4.9 \times 10^{3}$ with mean value of $3.2 \times 10^{3} / \mathrm{g}$. It is evident from the same table that the count of Listeria spp. in the imported frozen mackerel fish samples ranged from $5 \times 10^{4}$ to $18.4 \times 10^{4}$ with a mean value of $11.3 \times 10^{4} / \mathrm{g}$. The difference in the obtained results may be due to the differences between strains, the type of freezing employed, the length of time of freezing storage, temperature of freezing and also the nature and composition of the food.

The drug susceptibility is one of the important factors of characterization of L. monocytogenes antibiogram sensitivity test indicated that Norfloxacin and Chloramphenicol were the most effective antibiotics, while Kanamycin, Garamycin and Ampicillin were not effective antibiotics. The other used antibiotic showed different degrees of antimicrobial sensitivity reaction (Table3). Norfloxacin and choramphenicol are considered as the antibiotic of choice (Ibrahim and Hassan, (2006) Ebraheem and Thabet, (2007). The presences of Listeria in frozen products supports the statement that freezing has no significant effect on the organism (Sneath, et al., 1986).

In conclusion the information given by the achieved results revealed that the incidence of Listeria spp. was higher in frozen mackerel fish than that in frozen meat. The main purpose of this study was carried out to investigate the incidence of L. monocytogenes in imported frozen meat and mackerel fish in Assiut city. The public health importance as well as some recommended measures for improving the quality of such products were disscused. 


\section{ACKNOWLEDGEMENT}

I wish to express my sincere thanks to prof. Dr. EL-Tamawy Professor of Bacteriology, Faculty of Medicine, Assiut University, for his help in Listeria serotyping.

\section{REFERENCES}

A.P.H.A (American Public Health Association) (1992): Compendium of Methods for the Microbiological Examination of Foods $3^{\text {rd }} \mathrm{Ed}$ American Public Health Association, Washington, D. C.,USA.

Ben Embarek, P.K. (1994): Presences, detection and growth of listeria monocytogenes in sea foods: a review. J. Food Microbiol. 23: 17-34 (CrossRef) (Medline).

Collee, J.G. and Miles, R.S. (1989): Tests for identification of bacteria Mackie and McCartney Practical Medical Microbiology, J.G. collee, J.P. Duguid, A.G. Fraser and B.P. Marmion (eds) Vol. 11, 13, ed, Churchill living stone, Edinburgh, London, PP: 141-159.

Cossart, P.; Pizarro-Cerda, J. and Lecuit, M. (2003): Invasion of mammalian cells by Listeria monocytogenes: functional mimicry to subvert cellular functions. Trends Cell Biol, 13, 23-31.

Dalton, C.B.; Gregory, J.; KriK, M.D.; Stafford, R.J.; Giveny, R.; Kraa, E. and Gould, D. (2004): Food borne disease outbreaks in Asutralia 1995-2000. Commun- Dis Intell., 28(2): 211-224 .

Demetrios, K.; Bori, M. and Antonios, M. (1996): Growth of Listeria monocytogenes in the whey cheeses, Myzi theria, Anthoyros, and Manouri during storage at 5, 12 and $22 \mathrm{C}^{\circ}$. J. food Prot., 59: 1193-1199.

Ebraheem Lubna M. and Thabet Manal H. (2007): Incidence of Listeria monocytogenes in frozen beef, poultry and fish in Assiut city. Assiut. Vet. Med. J. Vol. 53, No. 113 April 2007.

Elgazzar, M.M.M. and Sallam, Kh.L.A. (1997): Occurrence of Listeria monocytogenes and other Listeria spp. in meat products Alexandria J. Vet. Sci. (13): 415-422.

FAO (Food and Agriculture Organization) (1992): Food and nutrition paper, Manual of food quality control, microbiological analysis, Part 4. pp. 119-129. Food and Agriculture Organization of the United Nations Rome. 
Farber, J.M. and Peterkin, P.I. (1991): Listeria monocytogenes, a foodborne pathogen. MicrobiolRev. 55: 4511.

Farber, J.M.; Sanders, G.W. and Johniston, M.A. (1989): A survey of various foods for the presence of listeria species. J. Food Protect. 52: 456-458.

FDA. (1999): Bad Bug Book (food borne Pathogenic Microorganisms and Natural Toxins). Internet address: http://vm Cfsam. Fda. Gov/ mov/intro. Htm.)

Finegold, S.M. and Martin, W.J. (1982): Diagnostic Microbiology Ed., the C.V. Mosby Company, London.

Fletcher, G.C.; Rogers, M.L. and Wong, R.J. (1994): Survey of Listeria monocytogenes in NewZealand seafood. J. Aquatic Food Product Technology 3(2):13-24.

Gianfranceschi, M.; Gattuse, A.; Tartaro, S. and Aurel, P. (2003): Incidence of Listeria monocytogenes in food and environmental samples in Italy between 1990 and clinical samples Eur. J. Epidemiol., 18, 1001-1006.

Hassan, Z.; Purwati, E.; Radu, S.; Rahim, R.A. and Rusul, (2001): Prevalence of Listeria species and Listeria monocytogenes in meat and fermented fish in Malaysia southeast Asian J. Trop. Med. Public. Health. Jun; 32(2): 402-407.

Ibrahim Hala, S. and Hassan Hala, F. (2006): Contamination of some local fish with listeria monocytogenes and studying its characterization and control. Assiut Vet. J. Vol. 52: 109-127.

Lida, T.; Kanzaki, M.; Nakama, A.; Kokubo, Y.; Maruyama, T. and Kaneuchi, C. (1998): Detection of listeria monocytogenes in humans, animals and foods J. Vet. Med. Sci. 60: 1341-1343.

Jorensen, T.L.V. and Huss. H.H. (1998): Prevalence and growth of listeria monocytogenes in naturally contaminated seafood. Int .J. Food microbial. 47: 127-131 (CrossRef) (Medline)

Koneman, E.W.; Allen, S.D.; Janda, W.M.; Schreckenberger, P.C. and Winn, W.C. (1996): Introduction to Diagnostic Microbiology $6^{\text {th }}$ Ed., Lippincott Company. Philadelphia, USA.

Loncarevic, S.; Danielsson Tham, M.L.; Gerner Smidt, P.; Sahlstrom, L. and Tham, W. (1998): Potential sources of human listeriosis in Sweden. Food.

Margolles, A. Mayo and Clara, G. (2000): Phenotypic Characteraization of Listeria monocytogenes and L. innocua strains isolated from short ripened cheeses. Food Microbiol. 17: 461-467. 
Mena, C.; Almeida, G.; Carneiro, L.; Teixeira, P.; Hogg, T. and Gibbs, P.A. (2004): Incidence of listeria monocytogenes in different food products commercialized in Portugal Food products, 21: 213-216.

Nicolas, J.A. and Vidaud, N. (1987): Contribution aletude des Leseria presentes dans les denrees dorigine animale destinees a la consummation humaine. Rec. Med.Vet. 163 (3): 283-285.

Okutani, A.; Okada, Y.; Yamamoto, S. and Igimi, S. (2004): Nationwide survey of human listeria monocytogenes infection, Japan Epidemiol. Infect., 132: 769-772.

Paul, B.V.; Barry, S.H. and James, M. (1998): Microbiological quality of Australian beef carcass meat and frozen bulk packed beef. J. of Food Prot. 61: 437-443.

Pinner, R.W.; Schuchat, A.; Swaminathan, B.; Hayes, P.S.; Deaver, K.A.; Weaver, R.E.; Plikaytis, B.D.; Reeves, M.; Broome, C.V. and Wenger, J.D. (1992): Role of foods in sporadic listeriosis. 2. Microbiolgic and epidemiologic investigation. JAMA 267: 2046-2050.

Quinn, P.J.; Carter, M.E.; Markey, B.K.; Donnelly, W.J.C. and Leonard, F.C. (2002): Veterinary Microbiology and Microbial Disease. Great Britain by MPG, Book Ltd, Bodmin, Corn wall, UK.

Ronda, M.D. and Thakor, R.P. (1992): Listeria in seafoods. J. of Food protection Vol.55, (12): 1009-1015.

Ryser, E.T. and Marth, E.H. (1991): Listeria, listeriosis, and food safety. Dekker, NY.

Scange, J.A.; Grona, A.D.; Belk, K.E; Sofos, J.N.; Bellinger, G.R. and Smith, G.C. (2000): Microbiological contamination of raw beef trimmings and ground beef. Meat Science (56):145-152.

Schillinger, U.; Kaya, M. and Luka, F.K. (1991): Behaviour of listeria monocytogenes in meat and its control by a bactriocinproducing strain of lactobacillus. J. Appl. Bacteriol., 70: 473478.

Schuchat, A.; Deaver, K.A.; Wenger, J.D.; Plkaytis, B.D.; Rengold, A.I.; Broome, C. and The listeria study Group, (1992): Role of foods in sporadic literiosis. J. Am. Med. Assoc., 276: 20412045.

Simon, M.; Tarrayo, C. and Ferrer, M.D. (1992): Incidence of listeria monocytogenes in fresh foods in Barcelona (spain). Int. J. Food Microbiol. 16: 153-156. 
Sneath, P.H.A.; Mair, N.S.; Sharpe, M.E. and Holt, J.G. (1986): Bergeys Manual of Systematic Bacteriology, Vol. 2, Sect. 14. Williams and Wilkins, Baltimore.

Weagant, S.D.; Sado, P.N.; Colbum, K.G.; Torkelson, J.D.; Stanly, F.A.; Krane, M.H.; Shields, S.C. and Thayer, C.F. (1998): The incidence of Listeria species in frozen sea food. J. Food Prot. (51): 655-667.

Wong, H.Ch.; Wel-Liang, Ch. and Shiu-Jung, L. (1990): Incidence and characterization of listeria monocytogenes in foods available in Taiwan. Appl. Environ. Microbiol. (56): 3101-3104. 